I. A. Prokop

\author{
I. Horbachevsky Ternopil State Medical University
}

\title{
THE USE OF ENGLISH PROFESSIONAL TEXTS-RELATED EXERCISE SET FOR DEVELOPING COMMUNICATIVE COMPETENCE OF MEDICAL STUDENTS
}

\author{
ДВНЗ “Тернопільський державний медичний університет \\ імені І. Я. Горбачевського МОЗ України”

\begin{abstract}
ВИКОРИСТАННЯ СИСТЕМИ ВПРАВ ДО ФАХОВИХ ТЕКСТІВ КОМУНІКАТИВНОЇ КОМПЕТЕНЦІЇ СТУДЕНТІВ-МЕДИКІВ
\end{abstract} \\ АНГЛІЙСЬКОЮ МОВОЮ ДЛЯ ФОРМУВАННЯ ІНШОМОВНОЇ
}

The aim of the work - to suggest and provide grounds for a specially developed set of tasks and exercises aimed at skills progression in dealing with professionally oriented texts, which form medical students' professional communication ability.

Subject to the study is a set of exercises meant for formation of medical students' professional communication skills within a training cycle "Professional English". Exercises for the original professional text "Digestive system" aimed at developing both receptive and productive type of the students' speech activity are suggested. Theoretical methods of scientific study (analysis, synthesis, summarizing, explanation, classification, etc.) have been used in the study.

The main body. Learning professionally oriented foreign language is accomplished on the language and informational basis of original professional texts. The text ought to be a tutorial, providing a basis for its further discussion that contributes directly to the development of students' communicative competence and to the optimal acquisition of a foreign language by making it capacious and effective, provided it is based on well thought-out, systematic and purposeful activity using properly selected system of tasks and exercises. The latter should meet the following requirements: (1) to be aimed at solving a specific task in line with the ultimate training objective; (2) to consider the standard of students' speech efficiency; (3) to provide phased formation of professional knowledge, skills and abilities; (4) to be of problem type, thus contributing essentially to students' critical thinking and their active involvement in the training process.

Conclusion. The suggested system of tasks and exercises provides active work of medical students with an original professional text at practical training and contributes to the development of their communicative skills and abilities, thus enabling to participate actively in different types of communication. Presented task samples do not fully cover the whole variety of forms and methods in dealing with foreign professionally oriented texts that is promising in view of further scientific studies.

Key words: exercise system; professional English text; communicative competence.

Мета роботи - запропонувати й обгрунтувати спеціально розроблений комплекс завдань та вправ для розвитку навичок роботи з професійно орієнтованими текстами, які дають змогу формувати у студентів-медиків вміння спілкуватися на професійні теми.

Предметом дослідження є система вправ для формування навичок іншомовного професійного спілкування майбутніх медиків у межах тематичного циклу навчальних занять 3 дисципліни “Англійська мова за професійним спрямуванням”. Запропоновано зразки вправ до фахового автентичного тексту “Травна система” для розвитку рецептивних і продуктивних видів мовленнєвої діяльності студентів-медиків з даної тематики. У дослідженні використані теоретичні методи наукового дослідження (аналіз, синтез, узагальнення, пояснення, класифікація тощо).

Основна частина. Вивчення професійно орієнтованої іноземної мови здійснюється на автентичних фахових текстах, які є мовною та інформаційною основою. Текст може і повинен виступати засобом навчання, окреслюючи проблематику для подальшого його обговорення, що безпосередньо сприяє розвитку комунікативної компетентності студентів і значно оптимізує процес засвоєння іноземної мови, роблячи його містким та ефективним за умови, якщо він будується на основі продуманої, систематичної та цілеспрямованої роботи з використанням вдало підібраної системи завдань та вправ.

Вправи та завдання, як засіб формування мовної компетентності, мають відповідати таким вимогам: бути спрямованими на вирішення конкретного завдання відповідно до кінцевої мети навчання; враховувати рівень мовної підготовки студентів; забезпечувати поетапне формування професійних знань, навичок та умінь; мати проблемний характер, що суттєво сприяє активізації критичного мислення студентів та їх активному залученню до навчання.

Висновок. Запропонована система завдань і вправ забезпечує активну роботу студентів-медиків з автентичним фаховим текстом на практичному занятті, сприяє розвитку їхніх комунікативних умінь і навичок, що дасть змогу брати активну участь у різних видах спілкування. Описані у статті зразки завдань не вичерпують усього розмаїття форм і методів роботи студентів при опрацюванні фахових текстів іноземною мовою, що створює перспективу для подальших наукових досліджень.

Ключові слова: система вправ; англомовний професійно орієнтований текст; іншомовна комунікативна компетентність.

(C) I. A. Prokop 
Introduction. Teaching foreign language at nonlinguistic departments of higher educational establishments should be regarded as a means of delivering essential information, both social and professional; as a way of practising in using foreign informational sources in the professional activity, and as an instrument of training a specialist-to be for continuous studying. These can be accomplished through professionally oriented learning of the foreign language. The up-to-date professionally directed approach suggests that students should acquire an adequate capacity of foreign language communication in concrete professional, business and scientific spheres/situations, specifics of professional thinking taken into consideration [1].

Language competence can be developed through various exercises which should meet the following requirements: (1) to be aimed at solving a concrete task in accordance with the ultimate objective of training; (2) to consider students' speech level; (3) to provide stage-by-stage formation of professional knowledge, skills and abilities; (4) to be of problem type, thus contributing essentially to the activation of students' critical thinking and their active involvement in the training process.

The aim of the work - to suggest and provide grounds for a specially developed set of tasks and exercises aimed at skills progression in dealing with professionally oriented texts, which form medical students' professional communication ability.

Subject to the study is a set of exercises meant for formation of medical students' professional communication skills within a training cycle "Professional English". Exercises for the original professional text "Digestive system" aimed at developing both receptive and productive type of the students' speech activity are suggested.

Objective and content of major tasks conditioned on the use of theoretical research methods (analysis, synthesis, summarizing, explanation, classification, concrete definition, theoretical generalization of results), based on the analysis of reviewed scientific studies on the problem by the other authors, both native and foreign, as well as on the own experience in teaching "Professional English" for the $2{ }^{\text {nd }}$-year students of the Medical department.

The main body. As a basis for the formation of oral speech skills and as a communication motive, a foreign language text should satisfy the following requirements: (1) to consider specifics of future specialty and students' professional interests (professional orientation arouses interest to the language learning); (2) to be in conformity with the subject matter; (3) to further the solution of specific communicative tasks; to take into account socio-cultural practicalities, representing specifics of the language behaviour (ethical communicative principles); (4) to contain the factor of novelty; (5) to arouse interest [1-4].

It is not uncommon that, when working with a text, the teachers give preference to reading, translation, speech exercises, asking questions (mostly by the teacher), learning by heart and rendering. By doing so, they nullify the students' creativity. In addition, reproduction of what has been memorized can hardly be classified as "active" speech. Memorizing verbatim is ineffective, since the speech skills gained are not transferred into another situation and, if need be, the student fails to speak decent foreign language, i.e. can't find proper word equivalents, makes lexical and grammar mistakes and quite often avoids communicating.

Nowadays, competent-active approach implies changes in the content of education in order to create language competence of the student. The development of new knowledge has activity manner, so students are trying in various ways to apply their knowledge in practice.

Among characteristic features of competencies Akzhan M. Abdyhalykova identifies:

The versatility and the ability to use in daily life.

Interdisciplinary approach and versatility.

Forming the basis for the further development of thought, reflection and self-assessment" [5].

Jack C. Richards in his "Communicative Language Teaching Today” emphasizes basic principles underlying current communicative language teaching, e.g.:

"Language learning is facilitated when learners are engaged in interaction and meaningful communication;

Successful language learning involves the use of effective learning and communication strategies;

The role of the teacher in the language classroom is that of a facilitator, who creates a classroom climate conductive to language learning and provides opportunities for students to use and practice the language and to reflect on language use and language learning;

The classroom is a community where learners learn through collaboration and sharing, etc.” [6].

The above-said taken into account, the teacher's primary task is not to set reading classes as dull mechanical work, but as a speech interaction of student teacher, student - student, student - students, etc. Effective work with the text presumes a set of exercises, targeted both at the formation of speech skills and abilities (in particular, differentiation, reconstruction, 
transformation and construction of language units for the purpose of accomplishing a given learning task), and at the development of creative rethinking capabilities. Learning tasks and exercises properly considered by the teacher "provide opportunities for students to negotiate meaning, expand their language resources, notices how language is used, and take part in the meaningful interpersonal exchange" [6].

While developing a set of exercises, it is necessary to take into account a number of factors that affect foreign language mastering, in particular:

(1) Purpose (target), speech task (conditional or real);

(2) Student's speech activity level;

(3) Verbal form and content;

(4) Consecutive formation of student's language skills and abilities;
(5) Time frame for doing exercise;

(6) Expected results;

(7) Language material (verbal or/and non-verbal: text, pictures, diagrams, maps);

(8) Exercise type (oral, written);

(9) Type of activity (individual work, work in pairs, group work, etc.) [7].

Formation of students' language skills and abilities is much more effective due to applying linguodidactic model, which includes pretext, in-text and post-text stages of working with professional text. Each stage of work is provided with a special set of exercises aimed at solving a concrete task in accordance with the ultimate objective of training (tab. 1).

Pretext tasks are directed on the modelling of background knowledge necessary for text reception,

Table 1. Exercises purpose due to the stage of work with professional text

\begin{tabular}{|l|l|}
\hline \multicolumn{1}{|c|}{ Exercises sequence } & \multicolumn{1}{c|}{ Exercises purpose } \\
\hline $\begin{array}{l}\text { Pretext } \\
\text { exercises }\end{array}$ & $\begin{array}{l}\text { To arouse interest in the topic. } \\
\text { To allow students predicting the content of the text. } \\
\text { To pre-teach new vocabulary. } \\
\text { To eliminate semantic and language difficulties. }\end{array}$ \\
\hline $\begin{array}{l}\text { In-text } \\
\text { exercises }\end{array}$ & $\begin{array}{l}\text { To allow students checking if their predictions were correct. } \\
\text { To introduce students to the text for the first time. } \\
\text { To test the students' reading comprehension. } \\
\text { To continue formation of the appropriate skills and abilities. }\end{array}$ \\
\hline $\begin{array}{l}\text { Post-text } \\
\text { exercises }\end{array}$ & $\begin{array}{l}\text { To use semantic information of the text as a linguistic, verbal, and informative support for } \\
\text { the development of students' skills in oral and written communication. }\end{array}$ \\
\hline
\end{tabular}

on the elimination of semantic and language difficulties as well as on the development of "understanding strategy".

The teacher's task at the initial phase of working on foreign language professional text is to form students' interest in the particular subject, as well as to help in previewing the content and to obviate probable speech difficulties. "Teacher-student" dialogue is aimed at foreseeing the meaning content of a scientific text. For example: What is the title of the text?, What problems is the text supposed to deal with?, Guess the main issues discussed in the text, etc.

In particular, at the preceding phase of working on the text "Digestive Tract" [8] the students are supposed to answer the teacher's questions What is the role of the digestive system for the human beings?, What are the main organs of digestion?, Do you know any accessory organs involved in digestion?, What helps to digest food?, basing on the lexical material of the topic "Systems of the Human Body" they have previously learned.

For the students to comprehend the text "Digestive Tract” [8], the teacher suggests to look through it and to answer the following questions: How many parts is the text divided into?, How are these parts connected with each other?, How are these parts introduced?

To obviate difficulties in understanding the text, a system of tasks forming language guess and skills of word-formation can be suggested, for example: Find the words the stem-compounds bloodstream, sublingual, submandibular, gastrointestinal, nasopharynx, oropharynx, carbohydrate are formed from; Guess the verbs the nouns digestion, mastication, chewing, absorption, preparation, secretion are derived from; Find the meaning of the words bit, breakdown, deliver, dilate, flexure, intake, moisten, parietal, retain and other contextually.

Doing exercises aimed at the presentation of new vocabulary to the topic is essential: Translate and memorize the following words and phrases; Complete the sentences using one of the following medical terms; Find substitutes for the following word combinations. Then use them in the sentences of your own, etc.

Studying a foreign language, learner's growth in vocabulary must be accomplished by opportunities to 
become fluent with that vocabulary. This fluency can be partly achieved through doing a set of exercises/ tasks, the most efficient of which are:

Ranging tasks. The use of ranging tasks encourages interaction between students in mastering active vocabulary. Students are given a list of words that they should rank according to certain criteria (e.g. easy/ difficult to remember/to spell/to pronounce, etc.) and explain their decision.
Sorting and ranking activities. The learners are offered to group the terms denoting the organs of the digestive system into main / accessory, preparing food for intake / digesting food, etc.

Grouping words by collocations. Another way for learners to remember new words is to join them according to the words they are often found with. Students are given a list of adjectives and a list of nouns to match (tab. 2).

Table 2. Grouping Digestive System terms by collocations

\begin{tabular}{|l|l|}
\hline \multicolumn{1}{|c|}{ Adjective } & \multicolumn{1}{|c|}{ Noun } \\
\hline $\begin{array}{l}\text { accessory alimentary digestive } \\
\text { dilated gastrointestinal hard parietal salivary serous } \\
\text { small soft visceral }\end{array}$ & $\begin{array}{l}\text { bits canal coat enzyme gland } \\
\text { intestine layer organ palate } \\
\text { portion system tract }\end{array}$ \\
\hline
\end{tabular}

Synonyms / Antonyms exercises. These can be effective since this activity is based on words and phrases the students have already learned (e.g. Arrange the following words in pairs of synonyms / antonyms; Choose the best synonym or antonym for the word given).

Matching exercises. The learners are given a list of words from the text and a list of definitions that need to be matched.

Vocabulary quizzes. Using quizzes with students on vocabulary keeps them constantly learning words.

In-text stage of working on the English professional text should be directed at:

Studying the lexical content of the text, for example: Look through the text and find the key medical terms used. Trace them through the text. What are they repeated for?; Guess the meaning of unknown words; Using dictionary entries, give the definitions of unknown words;

Detecting causative relationships, for example: Join the beginning and the end of the sentences using the adverbs consequently, therefore, hence, so; Complete the sentences using introductory phrases of scientific English.

At this stage of working on the foreign scientific text the students carry out tasks meant for obtaining substantial information according to communicative goal, for example: Give the main idea of the text; Find the key sentences in the text; Chose the sentences, which describe...; Find (write, name) main (key) facts that tell about...; Find facts which confirm/deny/ characterize...; Point out conclusive sentences; What do the following refer to in the text?; Find in the text English equivalents of the following words and phrases and translate the sentences containing them; Substitute the words and phrases in bold type by close in their meaning from the text.

The objective of the $3^{\text {rd }}$ (final) stage is to use the content of the professional text as a linguistic/speech basis for the development of learners' communicative skills and habits. For this, the tasks focused on the text understanding and interpreting are required: Work with a partner to label each statement true (T) or false (F). If the statement is false, correct it so that it is true; Work in pairs. Ask and answer comprehension check questions on the contents of the text; Explain given in the text figures/pictures/drawings; Agree/disagree with the following statements...; Enlarge the following statements; Render in English.

Composing a marking table of three columns (What do I know? / What do I want to know? / What have I learned?) is another way of reading efficacy control with notes. When working on the text "Digestive Tract”, students may be suggested to compose a KWL chart (tab. 3).

By activating acquired information on the digestive system organs and their own imagination, the students, on behalf of a fictional character "Food", are expected to compose a short story of its "journey" through the alimentary canal:

Oral cavity $\rightarrow$ Pharynx $\rightarrow$ Oesophagus $\rightarrow$ Pyloric Sphincter

Stomach

The following pattern may be used: I am a piece of cake. Incisors take a bite of me. I am in the mouth. Saliva is getting me wet and the tongue is pushing me around the mouth. I'm getting soft ...

The following Vocabulary keys for interaction are useful for students to express verbally their surprise, 
Table 3. KWL chart: Stomach

\begin{tabular}{|c|l|l|}
\hline K & \multicolumn{1}{|c|}{ W } & \multicolumn{1}{c|}{ L } \\
\hline Know & \multicolumn{1}{c|}{ Want } & \multicolumn{1}{c|}{ Learn } \\
\hline What do I know? & \multicolumn{1}{c|}{ What do I want to know? } & What have I learned? \\
\hline $\begin{array}{l}\text { The stomach is a dilated portion of the } \\
\text { alimentary canal. It lies in the upper } \\
\text { abdomen under the diaphragm. In } \\
\begin{array}{l}\text { anatomy, the stomach is an organ in the } \\
\text { alimentary canal used to digest food. }\end{array}\end{array}$ & $\begin{array}{l}\text { (1) Anatomical regions of the } \\
\text { stomach; }\end{array}$ & $\begin{array}{l}\text { The stomach's primary function is not the } \\
\text { absorption of nutrients from digested food. } \\
\text { (3) Gastric enzymes. }\end{array}$ \\
$\begin{array}{l}\text { The main job of the stomach is to break } \\
\text { down large food molecules into smaller } \\
\text { ones, so that they can be absorbed into the } \\
\text { blood more easily. }\end{array}$ \\
\hline
\end{tabular}

consent, disagreement, dismay, or other emotions while discussing various situations or making dialogues on the relevant topic (tab. 4).

Students are recommended to use library recourses, the Internet or other sources of information to create their own Healthy Food Pyramid placing (a) carbohydrate (e.g. bread, cereal, paste, rice), (b) vegetable, (c) fruit, (d) dairy (e.g. milk, cheese, yoghurt), (e) protein (e.g. meat, poultry, fish, egg, beans), (f) fats, oil, sweets within the pyramid to show their value for the human body and substantiate their choice. Figure 1 may serve as an example.

Interactive discussion in groups of 3 learners contributes noticeably to the development of critical thinking ability, for example:

The digestive system is our favourite system of the body;

Food and the Digestive System;

Eating Healthy for Digestive Problems;

Tips for a Healthier Digestive System;

My own eating habits and making suggestions for change.

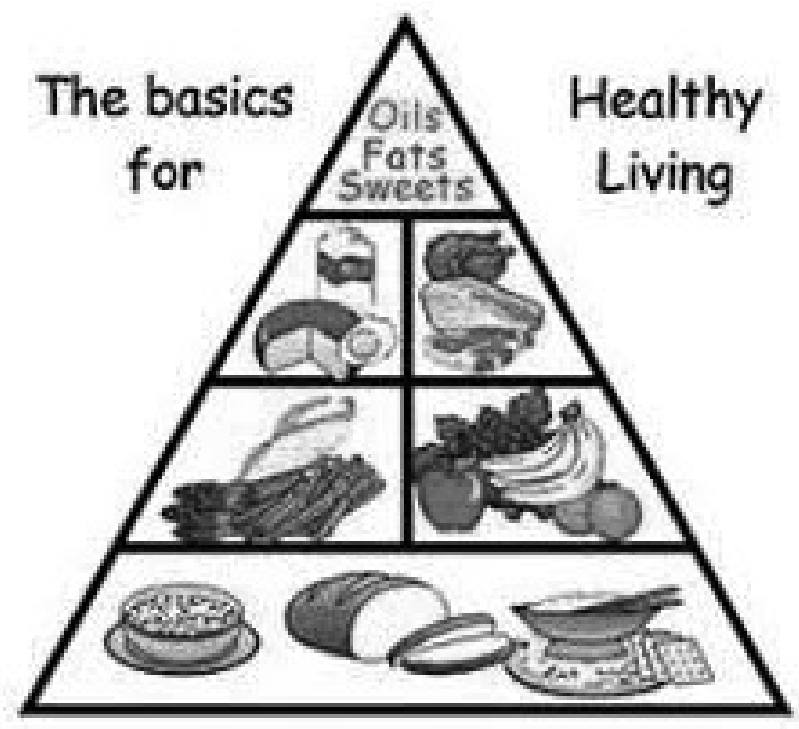

Fig. 1. Food Guide Pyramid

Conclusion. The suggested system of tasks and exercises provides active work of medical students with an original professional text at practical training and contributes to the development of their communicative

Table 4. Vocabulary keys for interaction

\begin{tabular}{|l|l|l|}
\hline \multicolumn{2}{|l|}{ Phrases expressing: } \\
\hline agreement & partial agreement & disagreement \\
\hline There is no doubt about it that... & It is only partly true that... & I don't agree with you. \\
I completely / absolutely agree & That's true, but... & I'm sorry, but I disagree. \\
with you. & I can agree with that only with & I'm afraid, I can't agree with you. \\
I agree with you entirely. & reservations. & The problem is that... \\
I totally agree with you. & That seems obvious, but... & I (very much) doubt whether... \\
I simply must agree with that. & That is not necessarily so. & This is in complete contradiction to... \\
I am of the same opinion. & It is not as simple as it seems. & I cannot share this / that / the view. \\
That's exactly what I think. & I agree with you in principle, but... & I cannot agree with this idea. \\
& I agree with you in part, but... & What I object to is... \\
& Well, you could be right. & I have my own thoughts about that. \\
\hline
\end{tabular}

skills and abilities, thus enabling to participate actively in different types of communication. Presented task samples do not fully cover the whole variety of forms and methods in dealing with foreign professionally oriented texts that is promising in view of further scientific studies. 


\section{List of literature}

1. Павлишин Г. Я. Іншомовний фаховий текст як основа для формування професійно орієнтованого мовлення студентів-медиків / Г. Я. Павлишин, І. А. Прокоп // Наукові записки Вінницького державного педагогічного університету імені Михайла Коцюбинського. Серія “Педагогіка і психологія” : зб. наук. праць. Вип. 41. Вінниця : ТОВ Нілан ЛТД, 2014. - С. 226-229.

2. Драб I. М. Комплекс вправ для навчання іншомовного професійного мовлення студентів-економістів / I. М. Драб // Іноземні мови. - 2003. - № 2. - С. 17-23.

3. Неділько А. Г. До питання застосування автентичних матеріалів для навчання іноземної мови / А. Г. Неділько // Іноземні мови. - 1998. - № 4. - С. 11-12.

4. Нуждина М. А. К вопросу управления процессом порождения речевого произведения на основе текста / М. А. Нуждина // Иностранные языки в школе. - 2002. № 2. - С. 21-25.

\section{References}

1. Pavlyshyn, H.Ya., \& Prokop, I.A. (2014). Inshomovnyi fakhovyi tekst yak osnova dlia formuvannia profesiino oriientovanoho movlennia studentiv-medykiv [Foreign language professional text as a basis for the formation of professionally oriented language competence of medical students]. V. I. Shakhov (Ed.). Naukovi zapysky Vinnytskoho derzhavnoho pedahohichnoho universytetu imeni Mykhaila Kotsiubynskoho. Seriia: Pedahohika i psykholohiia: Zb. nauk. prats - Scientific notes of Vinnytsia State Pedagogical University named after Mykhailo Kotsiubynskyi. Ser.: Pedagogy and Psychology: Collection of Scientific Works. (pp. 226-229). Vinnytsia: TOV Nilan LTD [in Ukrainian].

2. Drab, I.M. (2003). Kompleks vprav dlia navchannia inshomovnoho profesiinoho movlennia studentiv-ekonomistiv [A set of exercises for developing foreign-language professional communication of economics students]. Inozemni movy - Foreign Languages, 2, 17-23 [in Ukrainian].

3. Nedilko, A.H. (1998). Do pytannia zastosuvannia avtentychnykh materialiv dlia navchannia inozemnoi movy [On the application of authentic materials for teaching foreign language]. Inozemni movy - Foreign Languages, 4, 11-12 [in Ukrainian].

4. Nuzhdyna, M.A. (2002). K voprosu upravleniya protsessom porozhdeniya rechevohgo proizvedeniya na
5. Abdyhalykova A. M. Innovative methods of foreign languages teaching / A. M. Abdyhalykova. - Retrieved from: http://www.indjst.org/index.php/indjst/article/ viewFile/95561/70904.

6. Richards J. Communicative language teaching today / J. Richards. - Retrieved from: http://aaboori.mshdiau.ac.ir/ FavouriteSubjects/communicative-language-teachingtoday-v2.pdf.

7. Мусаелян И. Ф. Комплекс упражнений, направленных на формирование языковой компетенции / И. Ф. Мусаелян // Гуманитарные науки. Вестник Финансового университета. - 2014. - № 2 (14). - С. 74-78.

8. Прокоп I. А. Англійська мова за професійним спрямуванням : Медицина / І. А. Прокоп, В. Я. Рахлецька, Г. Я. Павлишин. - Тернопіль : ТДМУ, 2010. - 576 с.

9. Barrot J. Implementing task-based language teaching in ESL classrooms / J. Barrot // Advanced Science Letters. 2017. - Vol. 23, No. 2. - P. 944-947.

osnove teksta [On the issue of managing the process of generating speech product on the basis of text]. Inostrannyie yazyiki v shkole - Foreign Languages at School, 2, 21-25 [in Russian].

5. Abdyhalykova, A.M. Innovative methods of foreign languages teaching. Retrieved from: http://www.indjst.org/ index.php/indjst/article/viewFile/95561/70904.

6. Richards, J. Communicative language teaching today. Retrieved from: http://aaboori.mshdiau.ac.ir/ FavouriteSubjects/communicative-language-teachingtoday-v2.pdf.

7. Musaelyan, I.F. (2014) Kompleks uprazhneniy, napravlennykh na formirovanie yazykovoy kompetentsii [A set of exercises aimed at developing language competence]. Gumanitarnyye nauki. Vestnik Finansovogo universitetaHumanitarian Sciences. Journal of the Financial University, 2 (14), 74-78 [in Russian].

8. Prokop, I.A., Rakhletska, V.Ya., \& Pavlyshyn, H.Ya. (2010). Anhliiska mova za profesiinym spriamuvanniam: Medytsyna [Professional English: Medicine]. Ternopil: TDMU: Ukrmedknyha [in Ukrainian].

9. Barrot, J. (2017). Implementing task-based language teaching in ESL classrooms. Advanced Science Letters, 23 (2), 944-947. 